\title{
The relation between serum surfactant protein-d level and chronic obstructive pulmonary disease severity.
}

\author{
Fatma Çiftci*, Elif Şen, Gökçen Arkan, Duygu Acar, Sevgi Saryal \\ Department of Chest Disease, Ankara University School of Medicine, Ankara, Turkey
}

\begin{abstract}
Surfactant Protein D (SP-D), a glycoprotein released by type II pneumocytes, reportedly predicts pulmonary functional integrity and disease progression. The aim of this study was to define the relationship between SP-D level and COPD severity.

Sixty-three patients with stable COPD and 25 healthy control subjects were enrolled. Demographics and COPD severity according to GOLD 2013 staging criteria were evaluated. Arterial blood gases, pulmonary function tests, and exercise test were performed. CAT score, Charlson Comorbidity Index, St. George's Questionnaire scores, and BODE index were calculated. The relationship between SP-D level and COPD severity, dyspnea level, and quality of life was investigated.

According to GOLD 2013, 30 subjects were in group A, 12 in group $B, 12$ in group $C$, and 9 in group D. The serum SP-D level was significantly higher in the COPD group $(171.9 \pm 113.0 \mathrm{ng} / \mathrm{mL})$ than in the control group $(106.8 \pm 46.7 \mathrm{ng} / \mathrm{mL})(p<0.01)$. SP-D was significantly correlated to FEV1 $(p=0.01)$ and FEV1/FVC $(p<0.01)$. Furthermore, there was a significant negative correlation between SP-D and carbon monoxide diffusion capacity $(\mathrm{p}=\mathbf{0 . 0 3})$. There was a statistically significant correlation between SP-D and $\mathrm{PaCO}_{2}(\mathrm{p}=0.02)$. High-risk GOLD groups $(\mathrm{C}$ and $\mathrm{D})$ had a significantly higher SP-D level than the low-risk groups $(A$ and $B)(p=0.01)$. Serum SP-D level significantly correlated with the BODE index $(\mathbf{p}<\mathbf{0 . 0 1})$.

Serum SP-D was elevated in patients with COPD and associated with impaired lung function, high $\mathrm{PaCO}_{2}$ level and decreased diffusion capacity for carbon monoxide. In addition, the correlation found between serum SP-D levels and the BODE index could reflect the overall severity of COPD.
\end{abstract}

Keywords: Surfactant protein D, Chronic obstructive pulmonary disease, COPD, Biomarker, Pulmonary function tests. Accepted on January 08, 2018

\section{Introduction}

Chronic Obstructive Pulmonary Disease (COPD) is a common preventable and treatable disease characterized by persistent airflow limitation, which is usually progressive and associated with an enhanced chronic inflammatory response in the airways and lungs to noxious particles or gases. Exacerbations and comorbidities contribute to the overall severity in individual patients [1].

In COPD, systemic inflammation in which a wide range of inflammatory cells take part affects airways, lung parenchyma, and pulmonary circulation. Increased levels of proteases and oxidants in chronic airway inflammation lead to lung tissue breakdown and airflow limitation [2]. Increased airway and systemic inflammation causes physiologic alterations in COPD, such as hyperinflation $[3,4]$.

Inflammatory biomarkers have been used effectively for measuring COPD-associated airway and systemic inflammation, as well as monitoring anti-inflammatory action of treatment, particularly in the face of a high variability of the rate of decline of forced expiratory flow in one second $\left(\mathrm{FEV}_{1}\right)$ as an endpoint $[4,5]$. The search for a specific biomarker for lung has revealed that surfactant protein-D (SP-D) increases in COPD [6]. SP-D is a glycoprotein that belongs to the collectin protein family; it is secreted from alveolar type 2 cells and Clara cells [7]. Its basic function is to maintain surfactant hemostasis. In addition, it also possesses some antioxidant, anti-inflammatory, and immunologic functions. It plays an important role in the defense mechanisms against infections and allergens, binds to and mediates the clearance of many pathogens, boosts phagocytosis of apoptotic cells and prevents the release of proinflammatory cytokines from effector cells [8-11]. SP-D-deficient mice display an abnormal pulmonary phenotype characterized by activated alveolar macrophages, increased levels of matrix metalloproteases and emphysematous changes in lung parenchyma $[12,13]$.

Therefore, SP-D may be a promising biomarker reflecting health status of patients with COPD, such as progression of dyspnea and loss of respiratory function. Furthermore, we based this study on the hypothesis that unlike non-specific biomarkers such as C-reactive protein (CRP), tumor necrosis 
factor alpha, and fibrinogen, SP-D is a potential systemic lungspecific biomarker that could be used in COPD [14-16].

This study aimed to determine SP-D level in patients with stable COPD compared with healthy control subjects, and to investigate the correlation with COPD severity. The secondary aim was to explore the relationship between SP-D and lung function, dyspnea scores, and quality of life.

\section{Materials and Method}

The studies were conducted in accordance with the Declaration of Helsinki and Good Clinical Practice guidelines, and were approved by Ankara University School of Medicine Clinical Research Ethics Committee (02-41-11). Written and signed informed consent was obtained from all participants.

This study enrolled 63 patients with COPD (5 females, 58 males) who were under regular follow-up in the COPD outpatient clinic of a university hospital and 25 healthy control subjects ( 8 females, 17 males).

The COPD group included patients aged $40 \mathrm{y}$ or older who had a post-bronchodilator FEV1/Forced Vital Capacity (FVC) ratio of less than $70 \%$ and diagnosed as having COPD according to the Global Initiative for Chronic Obstructive Lung Disease (GOLD) criteria [17]. The control group included subjects aged 40 years or older who exhibited normal lung function (post-bronchodilator $\mathrm{FEV}_{1}>80 \%$ of predicted and $\mathrm{FEV}_{1} /$ FVC $>70 \%$ ).

The patients with COPD were not administered inhaled steroid for 4 weeks before the study. In addition, patients of both groups were in a clinically stable condition, thus, no recent increase in cough, sputum, or dyspnea; newly developed infiltrates on chest X-ray; inhaler or systemic steroid use for at least 4 weeks preceding inclusion; or hospitalization due to a COPD exacerbation within the last 3 months. Patients with any other lung disease, cancer in the past $5 \mathrm{y}$, known inflammatory disease (e.g. rheumatoid arthritis, inflammatory bowel disease and multiple sclerosis), stroke, severe ischemic heart disease, and severe kidney dysfunction, psychosocial or physical difficulties that might interfere with the assessments were excluded.

Detailed medical and smoking histories, occupational exposures, biomass exposures, and comorbidities were reported. Exacerbations and hospitalizations of patients with COPD within the last year based on medical records and patient declaration were recorded. Exacerbations were defined as worsening of COPD symptoms leading to hospitalization, a visit to the emergency room, or use of an antimicrobial agent and/or systemic corticosteroids as an outpatient [18].

Serum samples for complete blood count, urea, creatinine, alanine aminotransferase, aspartate aminotransferase, lipid profile, and CRP were collected and immediately sent to the central laboratory of Ankara University Medical Faculty. Chest $\mathrm{X}$-ray, arterial blood gas analysis, arterial oxygen saturation with pulse oximetry, respiratory function tests including spirometry, diffusion capacity for Carbon Monoxide (CO), plethysmografic lung volume measurements, and 6-minute Walking Test (6MWT) were performed. 6MWT was measured in a $20 \mathrm{~m}$ long corridor, based on the guidelines of the American Thoracic Society [19]. Four patients needed portable oxygen supplementation during the performance of 6MWT.

The COPD Assessment Test (CAT) score was evaluated for all patients with COPD [20]. The BODE (body mass index (BMI), airflow obstruction, dyspnea and exercise capacity) index was one of the composite indexes used in COPD. The BODE score was calculated for all patients with COPD [21]. Dyspnea was assessed according to the modified Medical Research Council (mMRC) scale [22].

The Charlson Comorbidity Index (CCI) was used to calculate the comorbidity scores of the patients with COPD [23]. The St. George's Quality of Life Questionnaire was completed by all patients with COPD [24].

Laboratory tests (complete blood count, urea, creatinine, alanine aminotransferase, aspartate aminotransferase, lipid profile, and CRP) and chest X-ray were also performed for the control group. To rule out COPD in the control group, spirometry was performed.

\section{Pulmonary function tests and arterial blood gas analysis}

Pulmonary function tests were performed using a clinical spirometer (SensorMedicsVmax spectra 229, Bilthoven, The Netherlands) according to the European Respiratory Society (ERS) standards [16]. We measured forced FVC, $\mathrm{FEV}_{1}$, $\mathrm{FEV}_{1} / \mathrm{FVC}$ ratio, and $\mathrm{CO}$ diffusion capacity (DLCO). Total Lung Capacity (TLC), Residual Volume (RV), Functional Residual Capacity (FRC), Inspiratory Capacity (IC) and Vital Capacity (VC) were measured using a body plethysmograph (Body box SensorMedics 6200 Autobox, Bilthoven, Netherland). The study enrolled a total of 25 healthy individuals with normal spirometry values and 63 patients with stage 1 (mild), stage 2 (moderate), stage 3 (severe), and stage 4 (very severe) COPD according to the GOLD criteria based on post-broncodilatator $\mathrm{FEV}_{1}$ values (post bronchodilator values were obtained after $400 \mathrm{mcg}$ salbutamol inhalation) [1].

GOLD 2013 disease severity classifications were used to define the patient group characteristics in order to determine whether serum SP-D levels might be a surrogate of disease severity in COPD. According to the severity of airflow limitation based on post-bronchodilator FEV1, patients were classified as mild $\left(\mathrm{FEV}_{1}>80 \%\right.$ of predicted), moderate $\left(\mathrm{FEV}_{1}\right.$ $50-80 \%$ of predicted), severe $\left(\mathrm{FEV}_{1} 30-50 \%\right.$ of predicted) and very severe $\left(\mathrm{FEV}_{1}<30 \%\right.$ of predicted). The patients were categorized into groups A, B, C, and D of GOLD 2013 staging. Group A included low-risk and less symptomatic patients, i.e., those with GOLD stages 1 or 2, and/or 0-1 exacerbations/year and no hospitalizations due to exacerbation, and a CAT score of $<10$, or mMRC of $0-1$. Group B included low-risk but more symptomatic patients, i.e., those with GOLD stages 1 or 2, and/or 0-1 exacerbations/year or no hospitalizations due to exacerbations, a CAT score of $\geq 10$, or $m M R C \geq 2$. 
Group $\mathrm{C}$ included high-risk patients with less symptoms, i.e., those with GOLD stages 3 or 4 , and/or $\geq 2$ exacerbations/year or $\geq 1$ hospitalizations due to exacerbation, a CAT score of $<10$ or mMRC $0-1$.

Group D included high-risk subjects with more symptoms, i.e., those with GOLD stages 3 or 4 , and/or $\geq 2$ exacerbations/year or $\geq 1$ no hospitalizations due to exacerbations, a CAT score of $\geq 10$ or $\mathrm{mMRC} \geq 2$.

Arterial blood gas analyses were performed at rest and in room air using an ABL 90 Flex/Blood Gas Analyzer (Radiometer Ltd. Bronshoj, Denmark). Partial pressure of oxygen $\left(\mathrm{PaO}_{2}\right)$, partial pressure of carbon dioxide $\left(\mathrm{PaCO}_{2}\right), \mathrm{pH}$, bicarbonate $\left(\mathrm{HCO}_{3}\right)$, and saturation of oxygen $\left(\mathrm{SaO}_{2}\right)$ were measured while breathing room air.

\section{Analysis of SP-D}

Venous blood samples taken during the daytime were put into biochemistry tubes and allowed to stand for $30 \mathrm{~min}$. The samples were then centrifuged at $1500 \mathrm{rpm}$ for $15 \mathrm{~min}$ at room temperature to separate the sera. The samples were then divided into aliquots using a sterile plastic transfer pipette, put into sterile plastic containers, and stored at $-80^{\circ} \mathrm{C}$ until required for biochemical analysis. When the adequate number of samples was reached, all stored samples were simultaneously thawed. Serum SP-D measurement was performed using a colorimetric sandwich Enzyme-Linked Immunosorbent Assay (ELISA) method (Biovendor, Modrice, Czech Republic) according to the manufacturer's instructions by operators who were blinded to each individual's lung disease or treatment group. All samples were studied twice.

\section{Statistical analysis}

Study data are expressed as mean \pm standard deviation for continuous variables and frequency (percentile) for categorical variables. Depending on the normality of data distribution, Student's t-test or Mann-Whitney $U$ test was used for independent group comparisons. The Chi-square test and Fisher's exact test were used for categorical variables. SP-D was compared using Kruskall-Wallis variance analysis because it did not show normal distribution by GOLD groups. Receiver-operating characteristic analysis assessed the optimal cut-off values of serum SP-D level for patients with COPD. Sensitivity, specificity and $95 \%$ confidence intervals (CI) were calculated. A P value of less than 0.05 was considered statistically significant. SPSS version 17.0 for Windows (SPSS Inc., Chicago, IL, USA) was used for all statistical analyses.

\section{Results}

The demographic properties of COPD and control groups are shown in Table 1. The mean ages of the COPD and control groups were $63.7 \pm 9.2$ and $53.8 \pm 8.2 \mathrm{y}$, respectively $(\mathrm{p}=0.49)$.
There were $5(7.8 \%)$ female subjects in the COPD group and 8 $(32 \%)$ in the control group $(\mathrm{p}<0.01)$.

Table 1. Comparison of the general properties of the COPD and control groups.

\begin{tabular}{|c|c|c|c|}
\hline & COPD $(n=63)$ & Control $(n=25)$ & $\begin{array}{l}\mathrm{p} \\
\text { value }\end{array}$ \\
\hline Age (y) & $63.7 \pm 9.2$ & $53.8 \pm 8.2$ & 0.49 \\
\hline BMI, $\mathrm{kg} / \mathrm{m}^{2}$ & $27.4 \pm 4.4$ & $29.5 \pm 4.0$ & 0.04 \\
\hline \multicolumn{4}{|l|}{ Smoking status } \\
\hline Current & $7(11.1)$ & $7(28)$ & $<0.01$ \\
\hline Former & $50(79.4)$ & $11(44)$ & 0.01 \\
\hline Non smoker & $6(9.5)$ & $7(28)$ & 0.03 \\
\hline Smoking history (pack-years) & $40.0 \pm 20.12$ & $22.1 \pm 13.1$ & $<0.01$ \\
\hline $\begin{array}{l}\text { Exacerbations within the last } \\
\text { year }(0 / 1 / 2)\end{array}$ & $\begin{array}{l}47 \quad(74.6) / 14 \\
(22.2) / 2(3.17)\end{array}$ & - & \\
\hline $\begin{array}{l}\text { Hospitalization within the last } \\
\text { year }\end{array}$ & $11(17.2)$ & - & \\
\hline $\mathrm{CRP}, \mathrm{mg} / \mathrm{L}$ & $6.2 \pm 11.5$ & $3.6 \pm 0.1$ & 0.26 \\
\hline SPD, ng/ml & $171.9 \pm 113.0$ & $106.8 \pm 46.7$ & $<0.01$ \\
\hline $\mathrm{SpO}_{2}, \%$ & $91.2 \pm 2.3$ & $97.3 \pm 2.0$ & 0.24 \\
\hline
\end{tabular}

Data are shown as mean \pm SD or $n(\%)$; BMI: Body Mass Index; SP-D Surfactant Protein D level; CRP: C-Reactive Protein, $\mathrm{SpO}_{2}$ : Arterial Oxygen Saturation with Pulse Oxymetry.

The COPD group had a significantly lower mean BMI than the control group $(27.4 \pm 4.4$ vs. $29.5 \pm 4.0 ; \mathrm{p}=0.04)$. Smoking status was significantly different between the COPD and control groups (Table 1). Mean CRP level was not significantly different between the two groups $(6.23 \pm 1.50$ vs. $3.3 \pm 0.01$, respectively; $\mathrm{p}=0.26$ ).

Serum SP-D levels were significantly higher in the COPD group $(171.9 \pm 113.0 \mathrm{ng} / \mathrm{mL})$ than in the control group $(106.8$ $\pm 46.7 \mathrm{ng} / \mathrm{mL})(\mathrm{p}<0.01)$ (Figure 1).

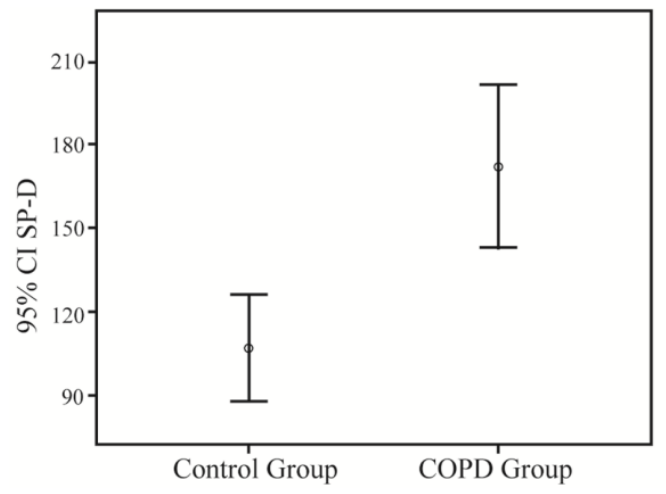

Figure 1. Error bar graphics showing serum SP-D levels of COPD and control group.

A cut-off point of serum SP-D levels for COPD was measured using the area under receiver-operating characteristic curve analysis (AUC of 0.76) (Figure 2). 


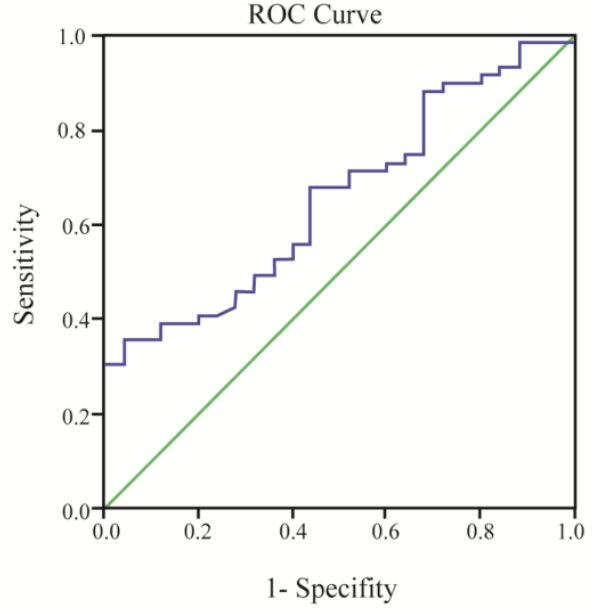

Figure 2. The Receiver-Operating Characteristics (ROC) curves of $S P-D$ in patients with COPD.

The sensitivity, specificity, 95\% CI's of SP-D for diagnosing COPD at the optimal cut-off level of $\geq 102.7 \mathrm{ng} / \mathrm{mL}$ was $79 \%$, $73 \%, 0.53$ and 0.77 , respectively. Arterial blood gas analysis, lung function tests are shown in Table 2 and 6MWT, CAT, Charlson comorbidity index, and St. George's Respiratory Questionnaire results of the patients with COPD subjects are shown in Table 3.

Table 2. Results of arterial blood gas analysis, expiratory flow rates, $C O$ diffusion capacity and lung volumes of patients with COPD.

\begin{tabular}{ll}
\hline & COPD (n=63) \\
\hline $\mathrm{PaO}_{2}, \mathrm{~mm} \mathrm{Hg}$ & $67.2 \pm 11.2$ \\
\hline $\mathrm{PaCO}_{2}, \mathrm{~mm} \mathrm{Hg}$ & $38.2 \pm 3.4$ \\
\hline $\mathrm{SaO}_{2}, \%$ & $93.4 \pm 4.3$ \\
\hline $\mathrm{FEV}, 1, \mathrm{~L}$ & $1.7 \pm 0.7$ \\
\hline $\mathrm{FEV}, \%$ predicted & $59.9 \pm 20.0$ \\
\hline $\mathrm{FVC}, \mathrm{L}$ & $2.9 \pm 0.8$ \\
\hline $\mathrm{FVC}, \%$ predicted & $81.5 \pm 16.6$ \\
\hline $\mathrm{DLCO}, \%$ predicted & $81.45 \pm 29.1$ \\
\hline $\mathrm{DLCO} / \mathrm{VA}, \mathrm{mL} / \mathrm{mm} \mathrm{Hg} / \mathrm{min} / \mathrm{L}$ & $99.7 \pm 26.1$ \\
\hline $\mathrm{IC}, \mathrm{L}$ & $2.9 \pm 0.8$ \\
\hline $\mathrm{FRC}, \%$ predicted & $125.8 \pm 28.8$ \\
\hline $\mathrm{TLC}, \%$ predicted & $113.4 \pm 16.8$ \\
\hline $\mathrm{RV}, \%$ predicted & $152.7 \pm 37.3$ \\
\hline $\mathrm{Data}$ a s & \\
\hline
\end{tabular}

Data are shown as mean $\pm \mathrm{SD}$ or $\mathrm{n}(\%) ; \mathrm{PaO}_{2}$ : Partial Oxygen Pressure; $\mathrm{PaCO}_{2}$ : Partial Carbon Dioxide pressure; $\mathrm{SaO}_{2}$ : Arterial Oxygen Saturation in Arterial Blood Gas; FEV 1 : Forced Expiratory Volume in the first second; FVC: Forced Vital Capacity; DLCO: Diffusing Capacity for Carbon Monoxide; DLCO/VA: Diffusion Capacity for Carbon Monoxide/Minute Ventilation Rate; IC:
Inspiratory Capacity; FRC: Functional Residual Capacity; TLC: Total Lung Capacity; RV: Residual volume.

Table 3. Results of 6-minute walking test, COPD Assessment test, Charlson comorbidity index, and St. George's Respiratory Questionnaire of patients with COPD.

\begin{tabular}{ll}
\hline & COPD $(\mathbf{n}=63)$ \\
\hline 6MWT, $m$ & $454.9 \pm 104.1$ \\
\hline CAT & $11.5 \pm 8.2$ \\
\hline BODE & $1.3 \pm 1.5$ \\
\hline CCI & $1.1 \pm 0.2$ \\
\hline SGRQ & $26.3 \pm 18.5$
\end{tabular}

6MWT: 6-Minute Walking Test; CAT: COPD Assessment Test; BODE: BODE Index; CCI: Charlson Comorbidity Index; SGRQ: St. George's Respiratory Questionnaire.

Table 4. Correlation of serum SP-D with various demographic properties and test results in patients with COPD.

\begin{tabular}{|c|c|c|}
\hline & $\begin{array}{l}\text { COPD group } \\
(n=63) \\
\text { r values }\end{array}$ & $p$ values \\
\hline Age, y & 0.135 & 0.31 \\
\hline $\mathrm{BMI}, \mathrm{kg} / \mathrm{m}^{2}$ & -0.06 & 0.63 \\
\hline Smoking history pack-years & -0.04 & 0.76 \\
\hline CRP, mg/L & 0.14 & 0.42 \\
\hline 6MWT, m & -0.05 & 0.73 \\
\hline Desaturation at 6MWT & -0.12 & 0.4 \\
\hline CAT & -0.01 & 0.96 \\
\hline BODE & 0.38 & $<0.01$ \\
\hline SGRQ & 0.07 & 0.59 \\
\hline $\mathrm{CCl}$ & 0.04 & 0.64 \\
\hline $\mathrm{FEV}_{1}, \%$ predicted & -0.32 & 0.01 \\
\hline $\mathrm{FEV}_{1}, \mathrm{~L}$ & $-0,27$ & 0.04 \\
\hline FVC, $\%$ predicted & -0.25 & 0.05 \\
\hline FVC, L & -0.17 & 0.19 \\
\hline $\mathrm{FEV}_{1} / \mathrm{FVC}$ & -0.34 & $<0.01$ \\
\hline $\mathrm{PaO}_{2}, \mathrm{~mm} \mathrm{Hg}$ & -0.13 & 0.36 \\
\hline $\mathrm{PaCO}_{2}, \mathrm{~mm} \mathrm{Hg}$ & 0.33 & 0.02 \\
\hline $\mathrm{DLCO}, \mathrm{mL} / \mathrm{mm} \mathrm{Hg} / \mathrm{min} / \mathrm{L}$ & -0.28 & 0.03 \\
\hline IC, L & -0.05 & 0.75 \\
\hline FRC, $\%$ predicted & 0.09 & 0.54 \\
\hline TLC, \% predicted & 0.01 & 0,94 \\
\hline RV, \% predicted & 0.1 & 0.55 \\
\hline
\end{tabular}


BMI: Body Mass Index; CRP: C-Reactive Protein; LDL: Low Density Lipoprotein; 6MWT: 6-Minute Walking Test; CAT: COPD Assessment Test; CCl: Charlson Comorbidity Index; SGRQ: St. George's Respiratory Questionnaire $F_{1}$ : Forced Expiratory Volume in the first second; FVC: Forced Vital Capacity; $\mathrm{PaO}_{2}$ : Partial Oxygen Pressure; $\mathrm{PaCO}_{2}$ : Partial Carbon Dioxide pressure DLCO: Diffusion Capacity for Carbon Monoxide; DLCO/VA: Diffusion Capacity for Carbon Monoxide-Minute Ventilation Rate; IC: Inspiratory Capacity; FRC: Functional Residual Capacity; TLC: Total Lung Capacity; RV: Residual Volume.

Table 4 shows how the demographic properties of the COPD group were correlated to the test results and SP-D levels. Serum SP-D levels had no significant correlation with age $(p=0.31)$, BMI $(p=0.63)$, smoking history or serum CRP level $(\mathrm{p}=0.42)$. The mean CAT score was measured as $11.5 \pm 8.2$. The CAT score was not correlated with SP-D $(p=0.82)$. Serum SP-D level was not significantly different between CAT scores $<10$ and CAT scores $\geq 10$ groups $(p=0.11)$. The BODE index $1.3 \pm 1.5$ was significantly correlated with SP-D $(\mathrm{p}<0.01)$. The mean six-minute walking distance was $454.9 \pm$ 104.1 meters. No statistically significant correlation was observed between serum SP-D and 6-minute walking distance or post-exercise desaturation. There was a statistically significant correlation between SP-D and $\mathrm{PaCO}_{2} \quad(\mathrm{r}=0.33$; $\mathrm{p}=0.02$ ). SP-D was significantly correlated to $\mathrm{FEV}_{1}(\mathrm{~L}), \mathrm{FEV}_{1}$ ( $\%$ predicted) and $\mathrm{FEV}_{1} / \mathrm{FVC}$ ratio $(\mathrm{r}=-0.27 ; \mathrm{p}=0.04, \mathrm{r}=-0.32$; $\mathrm{p}=0.01$ and $\mathrm{r}=-0.34 ; \mathrm{p}<0.01$, respectively). Furthermore, there was a significant negative correlation between SP-D and CO diffusion capacity $(\mathrm{r}=-0.28 ; \mathrm{p}=0.03)$. Lung volumes (IC (L) and TLC, FRC, RV, \% predictive) were not significantly correlated with SP-D $(p=0.75, p=0.79, p=0.55, p=0.56$, respectively). Serum SP-D level was not significantly different between the FRC $\%$ predictive $\geq 120$ and $<120$ groups $(p=0.08)$.

When the patients were classified according to severity of airflow limitation based on post-bronchodilator $\mathrm{FEV}_{1}, 4$ $(6.3 \%)$ patients were mild, $41(65 \%)$ were moderate, $12(19 \%)$ were severe, and $6(9.5 \%)$ had very severe disease. When they were classified according to the 2013 GOLD criteria, 30 (48\%) patients were in the GOLD A group, 12 (19\%) in the GOLD B group, $12(19 \%)$ in the GOLD C group and $9(14 \%)$ in the GOLD D group.

Table 5. Comparison of the SP-D levels of the patients with COPD grouped by $F E V_{1}$, percentage predicted.

\begin{tabular}{llll}
\hline & FEV $_{1}>\mathbf{5 0} \%$ & FEV $_{1}<50 \%$ & p \\
\hline Subjects, $\mathrm{n}(\%)$ & $45(71.4)$ & $18(28.6)$ & \\
\hline SP-D, ng/mL & $149.4 \pm 110.1$ & $227.3 \pm 103.1$ & $<0.01$ \\
\hline
\end{tabular}

Data are shown as mean \pm SD or $n(\%)$.

There were no statistically significant differences between serum SP-D level and airflow limitation stages (mild, moderate, severe, and very severe $)(p=0.06)$. When groups with $\mathrm{FEV}_{1}<50 \%$ and $\mathrm{FEV}_{1}>50 \%$ were compared, the former had a significantly higher serum SP-D level than the FEV $_{1}>50 \%$ group $(\mathrm{p}<0.01)$ (Table 5). GOLD A, B, C and D groups had no significant differences with respect to serum SPD level $(p=0.08)$. A multi-group comparison between the
GOLD A and B groups combined, GOLD C, and GOLD D groups revealed that the three groups had significantly different SP-D medians $(p<0.01)$. Serum SP-D level was significantly higher in the high-risk GOLD groups $(\mathrm{C}$ and $\mathrm{D})$ than in the low-risk GOLD groups (A and $B)(p=0.01)$ (Table 6).

Table 6. Comparison of the SP-D levels of the patients by GOLD group.

\begin{tabular}{llll}
\hline GOLD groups & A+B & C+D & p \\
\hline Patient's $n(\%)$ & $42(67)$ & $21(33)$ & \\
\hline SP-D, ng/mL & $149.4 \pm 110.1$ & $209.8 \pm 106.4$ & 0.01 \\
\hline Data are shown as mean + SD or $n(\%)$ & &
\end{tabular}

Data are shown as mean \pm SD or $n(\%)$.

\section{Discussion}

Recently, research has focused on the measurement of a variety of biomarkers that appear to exhibit prospective utility in the diagnosis of COPD. Serum levels of systemic markers of inflammation such as CRP and fibrinogen, which are validated in clinical laboratory assays, have been shown to reflect the degree of severity of airway inflammation, but they are not lung-specific [14-16]. SP-D is one of the biomarkers that resulted from the constant search for easy-to-use and noninvasive biomarkers for COPD. In the present study, we analyzed serum SP-D levels and assessed its clinical use in patients with COPD. We also explored the correlation between serum SP-D level and COPD severity, dyspnea severity, and quality of life in patients with COPD.

The present study found that serum SP-D levels were significantly and positively associated with COPD as compared with controls, in line with previous studies [25]. Serum SP-D concentrations of COPD group were higher than in the control group.

Systemic inflammation has a very important role at pathogenesis of COPD. The aim of the study was to evaluate the relationship between the SP-D which shows the degree of systemic inflammation in stable period, and COPD severity. For this reason instead of exacerbation stable disease stage was preferred.

A previous study created ROC curves based on 44 patients with stable COPD to evaluate the diagnostic accuracy of SP-D, and found a total area under the curve of 0.73 [26]. In the present study, the area under the curve was 0.76 for patients with COPD, which may be considered as similar to results reported in previous literature [26].

It is reasonable to assume that this and other proteins may leak into the blood stream when lung injury occurs in COPD because SP-D is mainly produced by lungs [27]. Although this may first be considered a paradoxical increase despite declining lung function, it has been confirmed in some animal studies [28].

Similar to other studies of patients with COPD, serum SP-D levels and $\mathrm{FEV}_{1}$ showed a negative correlation [29]. Reduced 
lung expression of SP-D was associated with lung injury and poor lung function. Furthermore, SP-D also showed variation between $\mathrm{FEV}_{1}<50 \%$ and $>50 \%$ groups. SP-D was also shown to be higher in more severe disease groups $(C$ and $D)$ compared with less severe groups (A and B) created on the basis of two variables, namely the number of exacerbations and dyspnea level. The finding of a significant negative correlation between SP-D level and DLCO may also indicate a correlation to the severity of pulmonary damage. Coxson et al. determined the extent of emphysema using computerized tomography scans in a longitudinal, international cohort of patients with COPD. Serum SP-D level was associated with decline in lung density. The authors explored the potential relation between emphysema and circulating SP-D level [30].

C-reactive protein has so far been the most extensively studied serum biomarker in COPD. Although it has shown good clinical correlation, it lacks desired specificity and thus has had limited clinical application. As such, virtually all inflammatory or infectious conditions lead to increased CRP levels, thus reducing specificity for COPD [31]. No significant correlation was shown between SP-D and CRP levels in patients with stable COPD in the current study. Akiki et al. measured serum SP-D, CRP, and fibrinogen levels in patients with COPD. In their study, SP-D levels were found significantly and positively associated with COPD, whereas serum CRP and plasma fibrinogen levels were not [32].

In contemplation of the possibility of inhaled steroids being able to affect lung-specific biomarker levels, we selected our patients from among patients with COPD who had not received inhaled steroids for at least 4 weeks. Inhaled fluticasone failed to reduce systemic levels of CRP or IL-6 but reduced serum SP-D levels, accompanied by improvement in lung function in patients with COPD in a multi-center clinical trial. This calls to mind that inhaled fluticasone only reduces lung-specific but not systemic inflammatory biomarkers, which supports the use of SP-D and other lung-specific protein markers [33].

We observed a positive correlation between serum SP-D levels and the BODE index in patients with COPD. As an index of disease severity with multiple dimensions of disease activity in COPD, the BODE index takes into account four independent predictors of survival with proven accuracy and power in a large cohort of patients with COPD; it may reflect significant fluctuations of health status of patients with COPD [34]. It is probably a better predictor of COPD outcomes than $\mathrm{FEV}_{1}$. Our study showed that there was no association between the 6MWD, mMRC, and serum SP-D levels. Therefore severity of disease has been found related to SP-D levels. We observed that SP-D level was not affected by the presence of comorbidities. This result suggests that SP-D is not affected by other systemic disorders and systemic inflammation they induce because it is a lung-specific biomarker.

We had no broncho-alveolar samples to compare with the serum levels. Previously, high levels of SP-D were demonstrated in bronchoalveolar lavage and induced sputum $[29,35]$. SP-D is principally produced in and secreted from type II pneumocytes in the lung and is found in the distal airways and alveoli, and also in the blood circulation. The higher serum SP-D level results of the present study make us think that invasive techniques like broncoalveolar lavage sampling are not needed in patients with stable COPD.

Herein, we detected an inverse correlation between lung function and serum SP-D levels in stable COPD. SP-D appears to be able to differentiate patients with COPD from a healthy control group. As a whole, our findings reflect that serum SP-D elevation may be a good predictor of declined lung function and other poor outcomes in patients with COPD. We thus suggest serum SP-D as a promising biomarker for monitoring disease progression and determining clinical outcomes in COPD. We speculate that serum SP-D may be useful as an intermediate measure in the development of anti-inflammatory therapies for COPD.

\section{Study Limitations}

The limitations of our study were the unequal number of female and male patients. We had a higher number of males in the study groups. This reflects the COPD prevalence in our country because smoking, biomass, and occupational exposure are far more common in men than women in Turkey, and COPD has a much higher prevalence in men. Some studies suggested that serum SP-D levels were affected by smoking, which may interfere with the homogeneity of serum SP-D concentration. Not all of our study patients were former smokers. This may be considered another limitation but we wanted to investigate real-life outcomes. Beside this, it is known that levels of serum SP-D are significantly elevated in individuals with COPD compared with current and former smokers without airflow obstruction [30]. We did not measure biomarkers other than CRP and SP-D. Thus, the use of other lung-specific molecules as potential biomarkers in COPD is not certain.

\section{Conflicts of Interest}

None.

\section{References}

1. COPD Diagnosis, Management, and Prevention. Global Initiative for Chronic Obstructive Lung Disease. GOLD 2016.

2. Hogg JC, Chu F, Utokaparch S. The nature of small-airway obstruction in chronic obstructive pulmonary disease. $\mathrm{N}$ Engl J Med 2004; 350: 2645-2653.

3. Barnes NC, Qiu Y-S, Pavord ID. Anti-inflammatory effects of salmeterol/fluticasone propionate in chronic obstructive lung disease. Am J Respir Crit Care Med 2006; 173: 736-743.

4. Lomas DA, Silverman EK, Edwards LD, Miller BE, Coxson HOR, Tal-Singer R. Evaluation of COPD Longitudinally to Identify Predictive Surrogate Endpoints (ECLIPSE) investigators. Evaluation of serum CC-16 as a biomarker for COPD in the ECLIPSE cohort. Thorax 2008; 63: 1058-1063. 
5. Vestbo J, Edwards LD, Scanlon PD. ECLIPSE Investigators. Changes in forced expiratory volume in 1 second overtime in COPD. N Engl J Med 2011; 365: 1184-1192.

6. Sin DD, Leung R, Gan WQ, Man SP. Circulating surfactant protein $\mathrm{D}$ as a potential lung-specific biomarker of health outcomes in COPD: a pilot study. BMC Pulm Med 2007; 7: 13.

7. Atochina EN, Gow AJ, Beck JM, Haczku A, Inch A, Kadire H, Tomer Y, Davis C, Preston AM, Poulain F, Hawgood S, Beers MF. Delayed clearance of pneumocystis carinii infection, increased inflammation, and altered nitric oxide metabolism in lungs of surfactant protein-D knockout mice. J Infect Dis 2004; 189: 1528-1539.

8. Ferguson JS, Voelker DR, Ufnar JA, Dawson AJ, Schlesinger LS. Surfactant protein D inhibition of human macrophage uptake of Mycobacterium tuberculosis is independent of bacterial agglutination. J Immunol 2002; 168: 1309-1314.

9. Hartshorn KL, Crouch E, White MR, Colamussi ML, Kakkanatt A, Tauber B, Shepherd V, Sastry KN. Pulmonary surfactant proteins A and D enhance neutrophil uptake of bacteria. Am J Physiol 1998; 274: 958-969.

10. Clark H, Palaniyar N, Hawgood S, Reid KB. A recombinant fragment of human surfactant protein $\mathrm{D}$ reduces alveolar macrophage apoptosis and proinflammatory cytokines in mice developing pulmonary emphysema. Ann N Y Acad Sci 2003; 1010: 113-116.

11. Borron PJ, Crouch EC, Lewis JF, Wright JR, Possmayer F, Fraher LJ. Recombinant rat surfactant-associated protein D inhibits human $\mathrm{T}$ lymphocyte proliferation and IL-2 production. J Immunol 1998; 161: 4599-4603.

12. Haczku A. Role and regulation of lung collectins in allergic airway sensitization. Pharmacol Ther 2006; 110: 14-34.

13. LeVine AM, Whitsett JA. Pulmonary collectins and innate host defense of the lung. Microbes Infect 2001; 3: 161-166.

14. Kushner I, Rzewnicki D, Samols D. What does minor elevation of C-reactive protein signify? Am J Med 2006; 119: 17-28.

15. Caramori G, Adcock IM, Di Stefano A, Chung KF. Cytokine inhibition in the treatment of COPD. Int J Chron Obstruct Pulmon Dis 2014; 9: 397-412.

16. Sand JM, Leeming DJ, Byrjalsen I, Bihlet AR, Lange P, Tal-Singer R, Miller BE, Karsdal MA, Vestbo J. High levels of biomarkers of collagen remodeling are associated with increased mortality in COPD-results from the ECLIPSE study. Respir Res 2016; 17: 125.

17. Vestbo J, Hurd SS, Agustí AG, Jones PW, Vogelmeier C, Anzueto A. Global strategy for the diagnosis, management, and prevention of chronic obstructive pulmonary disease: GOLD executive summary. Am J Respir Crit Care Med 2013; 187: 347-365.

18. Anthonisen NR, Manfreda J, Warren CP, Hershfield ES, Harding GK, Nelson NA. Antibiotic therapy in exacerbations of chronic obstructive pulmonary disease. Ann Intern Med 1987; 106: 196-204.
19. ATS Committee on Proficiency Standards for Clinical Pulmonary Function Laboratories. ATS statement: guidelines for the six minute walk test. Am J Respir Crit Care Med 2002; 166: 111-117.

20. Jones PW, Harding G, Berry P, Wiklund I, Chen WH, Kline Leidy N. Development and first validation of the COPD assessment test. Eur Respir J 2009; 34: 648-654.

21. Celli BR, Cote CG, Marin JM Casanova C, Montes de Oca M, Mendez RA, Pinto Plata V, Cabral HJ. The body-mass index, airflow obstruction, dyspnea, and exercise capacity index in chronic obstructive pulmonary disease. $\mathrm{N}$ Engl $\mathrm{J}$ Med 2004; 350: 1005-1012.

22. Bestall JC, Paul EA, Garrod R, Garnham R, Jones PW, Wedzicha JA. Usefulness of the Medical Research Council (MRC) dyspnoea scale as a measure of disability in patients with chronic obstructive pulmonary disease. Thorax 1999; 54: 581-586.

23. Charlson ME, Pompei P, Ales KL, MacKenzie CR. A new method of classifying prognostic comorbidity in longitudinal studies: Development and validation. J Chronic Dis 1987; 40: 373-383.

24. Jones PW, Quirk FH, Baveystock CM. The St George's respiratory questionnaire. Respir Med 1991; 85: 25-31.

25. Ju CR, Liu W, Chen RC. Serum surfactant protein D. Biomarker of chronic obstructive pulmonary disease. Dis Markers 2012; 32: 281-287.

26. Ilumets H, Mazur W, Toljamo T, Louhelainen N, Nieminen P, Kobayashi H, Ishikawa N, Kinnula VL. Ageing and smoking contribute to plasma surfactant proteins and protease imbalance with correlations to airway obstruction. BMC Pulm Med 2011; 11: 19.

27. Robin M, Dong P, Hermans C, Bernard A, Bersten AD, Doyle IR. Serum levels of CC16, SP-A and SP-B reflect tobacco-smoke exposure in asymptomatic subjects. Eur Respir J 2002; 20: 1152-1161.

28. Fujita M, Shannon JM, Ouchi H, Voelker DR, Nakanishi Y, Mason RJ. Serum surfactant protein D is increased in acute and chronic inflammation in mice. Cytokine 2005; 31: 25-33.

29. Ozyurek BA, Ulasli SS, Bozbas SS, Bayraktar N, Akcay S. Value of serum and induced sputum surfactant protein-D in chronic obstructive pulmonary disease. Multidiscip Respir Med 2013; 8: 36.

30. Coxson HO, Dirksen A, Edwards LD, Yates JC, Agusti A, Bakke P, Calverley PM, Celli B, Crim C, Duvoix A, Fauerbach PN, Lomas DA, Macnee W, Mayer RJ, Miller BE, Müller NL, Rennard SI, Silverman EK, Tal-Singer R, Wouters EF, Vestbo J. Evaluation of COPD Longitudinally to Identify Predictive Surrogate Endpoints (ECLIPSE) Investigators: The presence and progression of emphysema in COPD as determined by CT scanning and biomarker expression: a prospective analysis from the ECLIPSE study. Lancet Respir Med. 2013; 1: 129-136.

31. Kushner I, Rzewnicki D, Samols D. What does minor elevation of C-reactive protein signify? Am J Med 2006; 119: 17-28. 
32. Akiki Z, Fakih D, Jounblat R, Chamat S, Waked M, Holmskov U, Sorensen GL, Nadif R, Salameh P. Surfactant protein D, a clinical biomarker for chronic obstructive pulmonary disease with excellent discriminant values. Exp Ther Med 2016; 11: 723-730.

33. Sin DD, Man SF, Marciniuk DD, Ford G, FitzGerald M, Wong E, York E, Mainra RR, Ramesh W, Melenka LS, Wilde E, Cowie RL, Williams D, Gan WQ, Rousseau R. ABC (Advair, Biomarkers in COPD) Investigators: The effects of fluticasone with or without salmeterol on systemic biomarkers of inflammation in chronic obstructive pulmonary disease. Am J Respir Crit Care Med. 2008; 177: 1207-1214.

34. Ong KC, Lu Sj, Soh CS. Does the multidimensional grading system (BODE) correspond to differences in health status of patients with COPD? Int J Chron Obstruct Pulmon Dis 2006; 2: 91-96.
35. Sims MW, Tal-Singer RM, Kierstein S, Musani AI, Beers MF, Panettieri RA, Haczku A. Chronic obstructive pulmonary disease and inhaled steroids alter surfactant protein D (SP-D) levels: a cross-sectional study. Respir Res 2008; 9: 13 .

\section{*Correspondence to}

Fatma Çiftci

Department of Chest Disease

Ankara University School of Medicine

Ankara

Turkey 